\title{
Health Awareness in the Field of Eating Habits in Slovakia
}

\section{A. Plskova (Adriana Plskova)1, S. Paulik (Samuel Paulik) $)^{1}$, M. Kacmarikova

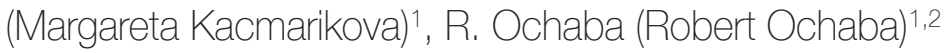

${ }^{1}$ Trnava University, Faculty of Health Sciences and Social Work, Department Original Article of Public Health, SK.

${ }^{2}$ Public Health Authority of the Slovak Republic, Department of Health Promotion and Health Education, Bratislava, SK.

\section{E-mail address:}

adriana.plskova@tvu.sk

\section{Reprint address:}

Adriana Plskova

Department of Public Health

Faculty of Health Sciences and Social Work

University in Trnava

Univerzitne nam. 1

91843 Trnava

Slovakia

Source: Clinical Social Work and Health Intervention

Volume: 12

Issue: 5

Pages: $41-46$

Cited references: 12

\section{Reviewers:}

Selvaraj Subramaniam

Kuala Lumpur

Zofia Szarota

Pedagogical University of Cracow, PL

\section{Keywords:}

Health Awareness. Eating Habits. Highly Nutritious Foods. Diseases of Civilisation. National Nutrition Recommendations.

\section{Publisher:}

International Society of Applied Preventive Medicine i-gap

CSWHI 2021; 12(5): 41 - 46; DOI: 10.22359/cswhi_12_5_06 CC Clinical Social Work and Health Intervention

\section{Abstract:}

Objectives: The aim of our research was to monitor the differences in the intake of food commodities according to gender and age in the Slovak Republic in 2019.

Design: Pilot study

Participants: The total number of respondents was 2,614 from all over the Slovak Republic, aged 15 to 65 years.

Methods: A questionnaire-based cross-sectional survey conducted in 2019 under the auspices of the Public Health Authority of the Slovak Republic (ÚVZ SR). For statistical analysis, we used the Chi-square test and Fisher's test, with a determined 
level of significance p-value $\leq 0.05$.

Results: With increasing age, women took more caloric food commodities compared to men who preferred foods of plant origin.

Conclusion: With increasing age, the intake of high-calorie foods increased in both sexes.

\section{Introduction}

In general, current eating habits can be defined as regular intake of foods with high energy and at the same time low nutritional value, while the intake of highly nutritious foods (fruits, vegetables, legumes) is suppressed. It is alarming that a majority of young people do not meet dietary recommendations. Their daily energy intake comes mainly from highly processed foods that contain excessive amounts of carbohydrates, fats, and synthetic ingredients and from sweetened beverages without nutritional value for the human body (Czoli et al., 2020). It is important to prefer high-fibre foods, fruits, vegetables, whole grain products, low-fat dairy products, white meat or nuts. Adherence to good dietary principles can reduce the risk of not only obesity but also of other cardiovascular diseases (Arghavan et al., 2019). Considering the changes in diet in recent decades, the aim of this article was to monitor the differences in the intake of individual food commodities according to gender and age in the Slovak Republic in 2019.

\section{Methodology}

A total number of respondents involved in the questionnaire survey which was conducted during the year was 2,614 respondents (men $\mathrm{n}=$ 1298; women $n=1316$ ) from all over the Slovak Republic. The questionnaire was compiled by the Public Health Authority of the Slovak Republic (ÚVZ SR) and was used to monitor the health awareness and behavior of the inhabitants of the Slovak Republic. This questionnaire was designed for respondents aged 15- 64 years. Data were collected in May and June by staff from health counselling departments of 36 regional public health offices. The questionnaire was provided in printed form. The collected data included socio-demographic data, the frequency of consumption of individual food commodities and the reduction in body mass index. The $\mathrm{R}$ project (version 3.2.2) was used for statistical analysis. Differences between the frequency of certain food commodity consumption and socio-demographic variables (gender, age, regions of the Slovak Republic) were analyzed using the Chisquare test (frequency $>5$ ) or Fisher's exact test (frequency $<5$ ). A p-value of $\leq 0.05$ was determined as the level of significance.

\section{Results}

We found statistically significant differences in individual food commodities. More women in the 19-25 age group (52\%) preferred daily consumption of pork compared to men in the same age category $(37 \%)(p=0.036)$. More young men in the $15-18$ age group (47\%) preferred poultry consumption over girls in the same age group $(35 \%)(p=0.049)$. More women in the $26-40$ age group $(79 \%)$ rarely chose to eat smoked meat products compared to men in the same age group $(62 \%)(\mathrm{p}=0.039)$. In fish and beef intake, we did not find statistically significant differences according to gender and age group (Table 1).

More women in the $19-25$ age group (56\%) preferred to consume eggs every day compared to men in the same age category $(47 \%)$ ( $\mathrm{p}=$ $0.049)$. More women in the 41-64 age group $(56 \%)$ preferred to eat pasta every day compared to men in the same age group (47\%) $(\mathrm{p}=0.046)$. We did not find statistically significant differences in milk intake (Table 2).

More women in the 19-25 age group (54\%) rarely preferred to consume vegetables compared to men in the same age category $(36 \%)$ ( $\mathrm{p}=$ $0.013)$. More women in the 41-64 age group $(54 \%)$ rarely preferred to consume legumes compared to men in the same age group (36\%) ( $\mathrm{p}=$ $0.021)$. We did not find statistically significant differences in fruit intake between men and women according to age group (Table 3 ).

\section{Discussion}

Eating habits in society have changed over the years, reducing the consumption of nutritious foods. This negative issue is the biggest problem, especially for the adolescent population, which 
has the worst diet in terms of nutritional quality compared to other age groups, and this gap will further widen. This phenomenon coincides with our study, where adolescents had the highest rate of consumption of fatty products and the lowest consumption of vegetables of all age categories while also representing the largest consumers of sweetened beverages. Consumption of alcoholic beverages was similar in all age categories, but the trend of alcohol consumption was stagnant.
Alcohol consumption is also increasing with age - studies have shown stronger trends in alcohol consumption in older age groups (Gigliotti Bessa, 2004; Galduroz et al., 2004). In addition to the harmful effects of alcohol on health, NHANES data from 2003-2008 found poorer food quality among men and women on the days they consumed alcohol, emphasizing higher total fat consumption and lower intake of fruit, milk, and dairy products (Breslow et al., 2013). In this

Table 1 Differences in the intake of meat food commodities according to gender and age category (ÚVZ SR, 2019)

\begin{tabular}{|c|c|c|c|c|}
\hline Food commodities & Age category & Men & Women & p-value \\
\hline \multirow{4}{*}{$\begin{array}{l}\text { Fresh fish } \\
a / b / c / d\end{array}$} & 15 - 18 years & $43 \% / 38 \% / 12 \% / 7 \%$ & $44 \% / 36 \% / 13 \% / 7 \%$ & 0,078 \\
\hline & 19 - 25 years & $7 \% / 19 \% / 25 \% / 49 \%$ & $6 \% / 15 \% / 24 \% / 55 \%$ & 0,085 \\
\hline & 26 - 40 years & $37 \% / 39 \% / 13 \% / 11 \%$ & $38 \% / 36 \% / 13 \% / 13 \%$ & 0,074 \\
\hline & $41-64$ years & $46 \% / 42 \% / 9 \% / 3 \%$ & $48 \% / 42 \% / 8 \% / 2 \%$ & 0,068 \\
\hline \multirow{4}{*}{$\begin{array}{c}\text { Pork } \\
\text { a/b/c/d }\end{array}$} & 15 - 18 years & $22 \% / 60 \% / 16 \% / 2 \%$ & $16 \% / 64 \% / 18 \% / 2 \%$ & 0,058 \\
\hline & 19 - 25 years & $37 \% / 40 \% / 18 \% 5 \%$ & $52 \% / 35 \% / 9 \% / 4 \%$ & 0,036 \\
\hline & 26 - 40 years & $14 \% / 49 \% / 29 \% / 8 \%$ & $19 \% / 53 \% / 22 \% / 6 \%$ & 0,051 \\
\hline & $41-64$ years & $5 \% / 43 \% / 45 \% / 7 \%$ & $6 \% / 42 \% / 44 \% / 8 \%$ & 0,094 \\
\hline \multirow{4}{*}{$\begin{array}{c}\text { Beef } \\
a / b / c / d\end{array}$} & 15 - 18 years & $18 \% / 72 \% / 8 \% / 2 \%$ & $14 \% / 71 \% / 13 \% / 2 \%$ & 0,081 \\
\hline & 19 - 25 years & $17 \% / 70 \% / 12 \% / 1 \%$ & $11 \% / 71 \% / 16 \% / 2 \%$ & 0,077 \\
\hline & 26 - 40 years & $9 \% / 64 \% / 23 \% / 4 \%$ & $8 \% / 66 \% / 24 \% / 2 \%$ & 0,063 \\
\hline & $41-64$ years & $50 \% / 28 \% / 14 \% / 8 \%$ & $53 \% / 29 \% / 12 \% / 6 \%$ & 0,072 \\
\hline \multirow{4}{*}{$\begin{array}{l}\text { Poultry } \\
\text { a/b/c/d }\end{array}$} & 15 - 18 years & $47 \% / 28 \% / 14 \% / 11 \%$ & $35 \% / 31 \% / 15 \% / 19 \%$ & 0,049 \\
\hline & 19 - 25 years & $26 \% / 43 \% / 24 \% / 7 \%$ & $26 \% / 41 \% / 25 \% / 8 \%$ & 0,084 \\
\hline & 26 - 40 years & $45 \% / 28 \% / 18 \% / 9 \%$ & $47 \% / 23 \% / 17 \% / 13 \%$ & 0,073 \\
\hline & $41-64$ years & $17 \% / 38 \% / 19 \% / 26 \%$ & $10 \% / 22 \% / 25 \% / 43 \%$ & 0,053 \\
\hline \multirow{4}{*}{$\begin{array}{c}\text { Smoked meat } \\
\text { products } \\
\text { a/b/c/d }\end{array}$} & 15 - 18 years & $11 \% / 31 \% / 36 \% / 22 \%$ & $8 \% / 27 \% / 35 \% / 30 \%$ & 0,052 \\
\hline & 19 - 25 years & $9 \% / 40 \% / 41 \% / 12 \%$ & $4 \% / 42 \% / 46 \% / 7 \%$ & 0,053 \\
\hline & 26 - 40 years & $6 \% / 13 \% / 19 \% / 62 \%$ & $3 \% / 5 \% / 13 \% / 79 \%$ & 0,039 \\
\hline & $41-64$ years & $5 \% / 51 \% / 31 \% / 13 \%$ & $5 \% / 56 \% / 29 \% / 10 \%$ & 0,074 \\
\hline
\end{tabular}

${ }^{*} a / b / c / d=$ every day/ 1-2 times per week/1-2 times per month/rarely 
study, men preferred alcohol (beer) consumption over women.

Consumption of fruits and vegetables has a protective effect on the risk of obesity, type 2 diabetes mellitus, cardiovascular diseases and some types of cancer. The World Health Organization has stated that an estimated 2.7 million deaths registered worldwide in 2000 could have been prevented with adequate fruit and vegetable consumption (Lock et al., 2005).

In a Brazilian study, total fruit consumption increased in adults and older adults, but not in adolescents. In the Brazilian study, fruit consumption showed a declining trend with higher consumption recorded in the elderly population. Spanish researchers have reported adverse trends in vegetable consumption (Valdés et al., 2009), but vegetable consumption has increased in the Portuguese population, as in this study. These findings are consistent with another study conducted in Sweden (Eiben et al., 2004) and in New Zealand (Laugesen - Swinburn, 2000). An examination of vitamin and mineral deficiencies was a pri- ority in 2006 which is why the Brazilian Nutrition Guidelines recommend growing fruit and vegetables - for the supply of fiber and vitamins such as carotenoids, with an emphasis on the consumption of dark green and orange vegetables (IBGE, 2011). The score of dark green vegetables and legumes in the group of adolescents also decreased.

According to 2008 data from the IBGE (2011), food groups, whose presence in the diet steadily increased along with the level of household income, were meat, milk and dairy products, fruits and vegetables. On the other hand, among the negative indicators of food quality was higher intake of sweet foods, soft drinks, pizza and bakery products. The presence of soft drinks in the diet was 5 times higher with a higher financial income than in the group with a lower financial income. In this study, an increased dietary quality score was observed among adults and older adults, mainly due to increased fruit intake and decreased saturated fat intake. However, the overall consumption for all food groups has been inadequate and remains a cause for concern. The

Table 2 Differences in milk, egg and pasta intake according to gender and age category (ÚVZ SR, 2019)

\begin{tabular}{|c|c|c|c|c|}
\hline Food commodities & Age category & Men & Women & p-value \\
\hline \multirow{4}{*}{$\begin{array}{c}\text { Milk } \\
\text { a/ b/ c/ d }\end{array}$} & $15-18$ years & $34 \% / 38 \% / 16 \% / 12 \%$ & $30 \% / 37 \% / 15 \% / 18 \%$ & 0,094 \\
\cline { 2 - 5 } & $19-25$ years & $47 \% / 42 \% / 9 \% / 2 \%$ & $47 \% / 43 \% / 8 \% / 2 \%$ & 0,159 \\
\cline { 2 - 5 } & $26-40$ years & $20 \% / 65 \% / 13 \% / 2 \%$ & $12 \% / 66 \% / 20 \% / 2 \%$ & 0,058 \\
\cline { 2 - 5 } & $41-64$ years & $46 \% / 39 \% / 12 \% / 3 \%$ & $48 \% / 37 \% / 12 \% / 5 \%$ & 0,066 \\
\hline \multirow{4}{*}{$\begin{array}{c}\text { Eggs } \\
\text { a/ b/c/d }\end{array}$} & $15-18$ years & $6 \% / 69 \% / 23 \% / 2 \%$ & $5 \% / 67 \% / 24 \% / 4 \%$ & 0,079 \\
\cline { 2 - 5 } & $\mathbf{2 6 - 4 0}$ years & $36 \% / 31 \% / 18 \% / 15 \%$ & $33 \% / 29 \% / 17 \% / 21 \%$ & 0,072 \\
\cline { 2 - 5 } & $41-64$ years & $21 \% / 43 \% / 27 \% / 9 \%$ & $19 \% / 42 \% / 29 \% / 10 \%$ & 0,061 \\
\hline \multirow{3}{*}{$\begin{array}{c}\text { Pasta } \\
\text { a/ b/c/ d }\end{array}$} & $15-18$ years & $26 \% / 52 \% / 17 \% / 5 \%$ & $23 \% / 59 \% / 16 \% / 1 \%$ & 0,094 \\
\cline { 2 - 5 } & $\mathbf{2 6 - 4 0}$ years & $18 \% / 44 \% / 27 \% / 11 \%$ & $18 \% / 47 \% / 26 \% / 9 \%$ & 0,052 \\
\cline { 2 - 5 } & $41-64$ years & $47 \% / 22 \% / 15 \% / 16 \%$ & $56 \% / 15 \% / 12 \% / 17 \%$ & 0,046 \\
\hline
\end{tabular}

${ }^{*} a / b / c / d=$ every day/ 1-2 times per week/1-2 times per month/ rarely 
biggest worries were caused by the data found in the group of adolescents who had the worst quality of diet which tended to decline further. Compared to other age groups, adolescents make worse choices of consumed foods. Studies show that adolescents prefer highly processed foods rich in sugar and fat, which affect health during developmental stages (USDA, 2009; Andrade et $a l ., 2010)$. The IBGE survey (2011) confirms a significant increase in the proportion of overweight Brazilian adolescents. In this study, significant differences were observed only in adolescent women.

The study has several limitations, the first being a short follow-up period. Positives include the adequate distribution of respondents according to gender and the time-saving nature of data collection.

Despite the limitations, differences in eating habits were demonstrated among respondents, which provide evidence of the urgent need for measures to improve the quality of diet in society as a whole, with respect to adolescents. This in- formation may support the development of measures to encourage the consumption of specific groups of foods, such as fruit and vegetables, milk and dairy products and wholegrain products, while supporting the reduction of added sugar and sodium by food producers. It is essential to realize that eating habits are modifiable lifestyle factors. The role of national nutrition guidelines with regard to public health needs to be emphasized. Appropriate implementation for target groups can significantly reduce the incidence of not only overweight and obesity, but also of other diseases of civilization, which significantly affect the quality of life.

\section{Conclusion}

With increasing age, the intake of high-calorie foods increased in both sexes. Obesity and overweight have been increasing especially in adults and adolescent girls. Given that diet is a modifiable lifestyle factor, the role of national nutrition recommendations needs to be emphasized.

Table 3 Differences in fruit, vegetable and legumes intake according to gender and age category (ÚVZ SR, 2019)

\begin{tabular}{|c|c|c|c|c|}
\hline Food commodities & Age category & Men & Women & p-value \\
\hline \multirow{4}{*}{$\begin{array}{l}\text { Vegetable } \\
a / b / c / d\end{array}$} & 15 - 18 years & $46 \% / 23 \% / 19 \% / 12 \%$ & $49 \% / 23 \% / 14 \% / 14 \%$ & 0,088 \\
\hline & 19 - 25 years & $8 \% / 27 \% / 29 \% / 36 \%$ & $5 \% / 17 \% / 24 \% / 54 \%$ & 0,013 \\
\hline & 26 - 40 years & $5 \% / 27 \% / 39 \% / 29 \%$ & $4 \% / 18 \% / 37 \% / 41 \%$ & 0,051 \\
\hline & $41-64$ years & $62 \% / 13 \% / 11 \% / 14 \%$ & $71 \% / 11 \% / 7 \% / 11 \%$ & 0,064 \\
\hline \multirow{4}{*}{$\begin{array}{c}\text { Fruit } \\
\mathrm{a} / \mathrm{b} / \mathrm{c} / \mathrm{d}\end{array}$} & 15 - 18 years & $2 \% / 7 \% / 16 \% / 75 \%$ & $1 \% / 3 \% / 8 \% / 88 \%$ & 0,058 \\
\hline & 19 - 25 years & $6 \% / 28 \% / 29 \% / 37 \%$ & $9 \% / 25 \% / 29 \% / 37 \%$ & 0,077 \\
\hline & 26 - 40 years & $1 \% / 18 \% / 41 \% / 40 \%$ & $3 \% / 16 \% / 40 \% / 41 \%$ & 0,069 \\
\hline & $41-64$ years & $1 \% / 9 \% / 37 \% / 53 \%$ & $1 \% / 11 \% / 33 \% / 55 \%$ & 0,087 \\
\hline \multirow{4}{*}{$\begin{array}{l}\text { Legumes } \\
a / b / c / d\end{array}$} & 15 - 18 years & $1 \% / 3 \% / 21 \% / 75 \%$ & $0 \% / 1 \% / 10 \% / 89 \%$ & 0,059 \\
\hline & 19 - 25 years & $2 \% / 22 \% / 40 \% / 36 \%$ & $2 \% / 28 \% / 44 \% / 26 \%$ & 0,061 \\
\hline & 26 - 40 years & $1 \% / 16 \% / 43 \% / 40 \%$ & $2 \% / 17 \% / 51 \% / 30 \%$ & 0,055 \\
\hline & $41-64$ years & $12 \% / 34 \% / 26 \% / 28 \%$ & $2 \% / 13 \% / 29 \% / 56 \%$ & 0,021 \\
\hline
\end{tabular}

${ }^{*} a / b / c / d=$ every day/ 1-2 times per week/1-2 times per month/ rarely 


\section{Declaration}

The questionnaire in the submitted work was anonymous. At the beginning of the questionnaire respondents received information about the purpose of the questionnaire and its evaluation. The authors have no conflict of interest.

\section{References}

1. ANDRADE S C et al. (2010) Dietary quality index and factors among adolescents of the state of Sao Paulo, Brazil. In J. Pediatr. vol. 156, no. 3, pp, 456-460.

2. ARGHAVAN H et al. (2019) Association of adherence to the dietary approach to stop hypertension diet and diet quality indices among women in Tehran: A cross- sectional study. In Health Promot Perspect. vol. 9, no. 4, pp. 198-291.

3. BRESLOW R A et al. (2013) Diets of drinkers on drinking and nondrinking days: NHANES 2003-2008. In Am. J. Clin. Nutr. vol. 97, no. 5, p. 1068-1075.

4. CZOLI E et al. (2020) Exposure to Food and Beverage Advertising on Television among Canadian Adolescents. In MDPI, Nutrients. vol. 12, p. 428.

5. EIBEN G et al. (2004) Secular trends in diet among elderly Swedes - cohort comparisons over three decades. In Public Health Nutr. vol. 7, pp. 637-644.

6. GALDUROZ R et al. (2004) Trends in drug use among students in Brazil: analysis of four surveys in 1987, 1989, 1993 and 1997. In Braz.J.Med. Biol.Res. vol. 37, pp. 523-531.

7. GIGLIOTTI A, BESSA M A (2004) Síndrome de dependência do álcool: critérios diagnósticos. In Rev. Bras. Psiquiatr. vol. 26, no. 1, pp. 11-13.

8. INSTITUTO BRASILEIRO DE GEOGRAFIA E ESTATÍSTICA (IBGE) (2011) Coordenação de Trabalho e Rendimento. Pesquisa de orçamentos familiares 20082009: análise do consumo alimentar pessoal no Brasil. In IBGE. p. 150.

9. LAUGESEN M, SWINBURN B (2000) The New Zealand food supply and diet-trends 1961-1995 and comparison with other OECD countries. Organization for economic co-operation and development. In: N.Z. Med. J.pp. 311-315.

10. LOCK K et al. (2005) The global burden of disease attributable to low consumption of fruit and vegetables: implications for the global strategy on diet. In: Bulletin. World Health Organ. vol. 83, no. 2, pp. 100-108.

11. THE UNITED STATES DEPARTMENT OF AGRICULTURE (USDA) (2013) Diet quality of Americans in 2001-02 and 2007-08 as measured by the Healthy Eating Index 2010. In: Nutrition Insight. vol. 51.

12. VALDES J et al. (2009) Secular trends in energy intake and diet quality in a Mediterranean population. In: Ann. Nutr. Metab., vol. 54, p. 177-183. 